\title{
Correction to: The Altered States of Consciousness in Transpersonal Approach Psychotherapy: Systematic Review and Guidelines for Research and Clinical Practice
}

\section{Milena Nardini-Bubols ${ }^{1}$ (D) Daniele Silva da Silva ${ }^{1} \cdot$ Andrea dos Santos-Silva $^{1}$. Olivia Kacey Stagnaro ${ }^{2}$ - Tatiana Quarti Irigaray ${ }^{1} \cdot$ Letícia Oliveira Alminhana $^{1}$}

Published online: 15 July 2019

(C) Springer Science+Business Media, LLC, part of Springer Nature 2019

\section{Correction to: Journal of Religion and Health https://doi.org/10.1007/s10943-019-00855-1}

The original version of this article unfortunately contained a mistake in the author name. The co-author name should be Letícia Oliveira Alminhana instead of Letícia de Oliveira Alminhana.

The original article has been corrected.

Publisher's Note Springer Nature remains neutral with regard to jurisdictional claims in published maps and institutional affiliations.

The original article can be found online at https://doi.org/10.1007/s10943-019-00855-1.

Milena Nardini-Bubols

milenabubols@gmail.com

Daniele Silva da Silva

daniele.silvadasilva@gmail.com

Andrea dos Santos-Silva

andreadosantos2011@gmail.com

Olivia Kacey Stagnaro

olivia.stagnaro@gmail.com

Tatiana Quarti Irigaray

tatiana.irigaray@pucrs.br

Letícia Oliveira Alminhana

leticiaalminhana@gmail.com

1 Graduation Program of Psychology, Pontifical Catholic University of Rio Grande do Sul/ PUCRS/BR, 493 Manoel Bandeira st., Porto Alegre 91215-330, Brazil

2 Graduation Program of Psychology, Santa Clara University, Santa Clara, USA 